"TURYZM" 1993 , t. 3, z. 1.

Christian Pihet, Philippe Violier

\title{
LOURDES. PRZESTRZEŃ MIEJSKA I FUNKCJA TURYSTYCZNA
}

\section{L'ACCUEIL A LOURDES: ESPACE URBAIN ET FONCTION TOURISTIQUE}

\section{LOURDES. URBAN SPACE AND TOURISTIC FUNCTION}

\begin{abstract}
W artykule zaprezentowano wyniki badań terenowych prowadzonych w $1990 \mathrm{r}$. na obszarze miasta Lourdes, największego sanktuarium maryjnego Francji. Badania te dotyczyły opinii różnych grup pielgrzymów na temat przyjęcia w Lourdes oraz warunków pobytu w tym mieście. W wyniku przeprowadzonych studiów autorzy proponują restrukturyzację przestrzeni miejskiej Lourdes.
\end{abstract}

Rosnące zniechęcenie wakacjami spędzanymi w kąpieliskach i związaną z tym bezczynnością powoduje wśród mieszkańców krajów zachodnich zwiększone zainteresowanie turystyką miejską. Czy jednak miasta są przygotowane na przyjęcie zwiększonej liczby turystów? Przygotowanie to - naszym zdaniem - obejmuje organizację ruchu wewnątrz miasta oraz stopień (stan) wykształcenia usług, które muszą stanowić naturalne uzupełnienie podstawowych atrakcji turystycznych miasta. Problemy te stały się przedmiotem badań i obserwacji prowadzonych na terenie miasta Lourdes przez studentów turystyki Uniwersytetu w Angers (ESTHUA) na wspólne zamówienie - władz miasta i władz kościelnych.

Lourdes jest miastem masowych przyjazdów turystycznych, które sięgają tu rocznie $5 \mathrm{mln}$ osób, co w sposób bardzo ostry uwypukla problemy związane $\mathrm{z}$ ich przyjęciem. Specyfika konsumpcji turystycznej $\mathrm{w}$ tym mieście jest z pewnością bardzo indywidualna. Uważamy jednak, że zastosowane w badaniach podejście metodologiczne, jak również podniesione kwestie, mają znaczenie bardziej ogólne. 
W celu zbadania problemów związanych z przyjęciem i obshugą turystów na obszarze miasta Lourdes przeprowadziliśmy wśród przybyłych tam turystów dwie ankiety: szczegółowy kwestionariusz oraz szybki sondaż obejmujący osoby opuszczające sanktuarium. Przeprowadzono również wiele obserwacji, aby łatwiej zrozumieć otrzymane wyniki i pogłębić znajomość badanej problematyki. W pracy omówiliśmy najpierw ocenę jaką wydali miastu badani turyści, a następnie skonfrontowaliśmy ja z cechami napotkanej populacji turystycznej. Konfrontacje uzyskanych opinii i cech turystów zdają się wskazywać na kierunki przyszłej polityki miasta w zakresie przyjmowania przyjeżdżających, co stało sie podstawą pewnych propozycji przedstawionych przez nas w końcowej części opracowania.

\section{PRZYJĘCIE W LOURDES W OPINIACH BADANEJ GRUPY TURYSTÓW}

Spośród 527 ankietowanych osób 314 surowo ocenia organizację ruchu turystycznego w mieście, a jednocześnie tyle samo deklaruje zadowolenie z przyjęcia przez świadczących usługi właścicieli sklepów, hoteli, restauracji i przez władze (zarządzających) sanktuarium.

$\mathrm{Na}$ przykładzie badanej grupy osób obliczono wskaźnik zadowolenia. Zadowolenie turystów-pielgrzymów z przyjęcia, jakie spotkało ich w Lourdes, zostało wyliczone przez analizę cząstkową elementów składających się na ogólną opinię o pobycie w tym mieście z wykorzystaniem 4-stopniowej skali (niedostateczny, dostateczny, dobry, bardzo dobry). Pod uwage wzięto dwa podstawowe elementy składające się na ocenę pobytu w mieście: organizację ruchu turystycznego zarówno w czasie wjazdu do miasta jak i poruszania się po nim oraz obshugę, czyli jakość świadczonych usług, zarówno w mieście jak i w sanktuarium. Wyniki badań przedstawione zostały w tab. I. Zadowolenie turystów wyrażone zostało, dla każdego przyjętego stopnia skali, w \%, a następnie wyliczony był wskaźnik na 100 osób, mnożąc \% przez przyjęty współczynnik (calkowicie niezadowoleni $=1$, bardzo zadowoleni $=4$ ). $\mathrm{W}$ ten sposób można bylo dojść do uproszczonego wzoru matematycznego, który przyjmuje następującą postać:

$$
\mathrm{i}=\frac{\left(\%_{a} \times 1\right)+\left(\%_{b} \times 2\right)+\left(\%_{c} \times 3\right)+\left(\%_{d} \times 4\right)-100}{3}
$$

Analiza wyników badań wykazuje, iż turyści-pielgrzymi pozytywnie oceniają przyjęcie, z jakim spotkali się u świadczących usługi oraz w sanktuarium. Ocena ta plasuje się na wysokim poziomie (od 69 do 75 na 100), a stopień 
Ocena pobytu w Lourdes (wyniki badań ankietowych)

L'accueil a Lourdes un bon point pour les prestataires de service et le sanctuaire, mais un carton rouge pour la gestion des flux

\begin{tabular}{|c|c|c|c|c|c|c|c|c|c|}
\hline & & & Stopień & sfakcji & & & nik satys & cji na 100 & \\
\hline & & & & & & & & przyje & ający \\
\hline Wyszczególn & aienie & niedosta- & dosta- & dobry & bardzo & ogółem & piel- & w sposób & \\
\hline Wielkość ruchu & $\begin{array}{l}\text { liczba } \\
\%\end{array}$ & $\begin{array}{l}103 \\
24,5\end{array}$ & $\begin{array}{r}138 \\
32,8\end{array}$ & $\begin{array}{c}141 \\
33,5\end{array}$ & $\begin{array}{l}39 \\
9,3\end{array}$ & 43,0 & 61,7 & 41,7 & 39,7 \\
\hline Płynność ruchu & $\begin{array}{l}\text { liczba } \\
\%\end{array}$ & $\begin{array}{l}150 \\
35,7\end{array}$ & $\begin{array}{l}156 \\
37,1\end{array}$ & $\begin{array}{c}89 \\
21,2\end{array}$ & $\begin{array}{l}25 \\
6,0\end{array}$ & 32,7 & 34,0 & 36,0 & 31,0 \\
\hline Możliwość postoju & $\begin{array}{l}\text { liczba } \\
\%\end{array}$ & $\begin{array}{l}102 \\
34,5\end{array}$ & $\begin{array}{c}88 \\
29,7\end{array}$ & $\begin{array}{c}65 \\
22,0\end{array}$ & $\begin{array}{c}41 \\
14,0\end{array}$ & 38,7 & 54,0 & 43,3 & 30,7 \\
\hline $\begin{array}{l}\text { Komfort } \\
\text { zakwaterowania }\end{array}$ & $\begin{array}{l}\text { liczba } \\
\%\end{array}$ & $\begin{array}{l}10 \\
2,6\end{array}$ & $\begin{array}{c}80 \\
20,5\end{array}$ & $\begin{array}{r}147 \\
37,6\end{array}$ & $\begin{array}{l}154 \\
39,4\end{array}$ & 71,3 & 71,0 & 69,0 & 72,0 \\
\hline $\begin{array}{l}\text { Atmosfera } \\
\text { przyjęcia }\end{array}$ & $\begin{array}{l}\text { liczba } \\
\%\end{array}$ & $\begin{array}{l}13 \\
3,6\end{array}$ & $\begin{array}{c}53 \\
14,5\end{array}$ & $\begin{array}{r}124 \\
33,9 \\
\end{array}$ & $\begin{array}{r}176 \\
48,1\end{array}$ & 75,6 & 76,0 & 73,0 & 75,7 \\
\hline $\begin{array}{l}\text { Standard } \\
\text { restauracji }\end{array}$ & $\begin{array}{l}\text { liczba } \\
\%\end{array}$ & $\begin{array}{l}17 \\
3,9 \\
\end{array}$ & $\begin{array}{c}91 \\
20,9\end{array}$ & $\begin{array}{l}168 \\
38,6 \\
\end{array}$ & $\begin{array}{r}159 \\
36,6\end{array}$ & 69,3 & 69,3 & 71,0 & 69,0 \\
\hline $\begin{array}{l}\text { Przyjęcia } \\
\text { w restauracjach }\end{array}$ & $\begin{array}{l}\text { liczba } \\
\%\end{array}$ & $\begin{array}{l}17 \\
4,2\end{array}$ & $\begin{array}{c}78 \\
19,1\end{array}$ & $\begin{array}{l}144 \\
35,6\end{array}$ & $\begin{array}{r}168 \\
41,4\end{array}$ & 71,7 & 74,0 & - 69,7 & 70,0 \\
\hline $\begin{array}{l}\text { Sytuacja } \\
\text { sanitarna }\end{array}$ & $\begin{array}{l}\text { liczba } \\
\%\end{array}$ & $\begin{array}{l}10 \\
2,4\end{array}$ & $\begin{array}{c}73 \\
17,4 \\
\end{array}$ & $\begin{array}{r}183 \\
43,6 \\
\end{array}$ & $\begin{array}{c}154 \\
36,7\end{array}$ & 71,7 & 80,7 & 69,3 & 66,0 \\
\hline Handel & $\begin{array}{l}\text { liczba } \\
\%\end{array}$ & $\begin{array}{l}19 \\
4,4\end{array}$ & $\begin{array}{l}112 \\
25,8\end{array}$ & $\begin{array}{r}190 \\
43,8\end{array}$ & $\begin{array}{l}113 \\
26,0\end{array}$ & 63,7 & 67,7 & 68,7 & 60,3 \\
\hline
\end{tabular}

Uw a g a: Cztery pierwsze kolumny przedstawiają stopień satysfakcji ankietowanych osób. Liczby bezwzględne dotyczą ważnych odpowiedzi. Wskaźnik satysfakcji obliczono w oparciu o wzór zamieszczony w tekście. 


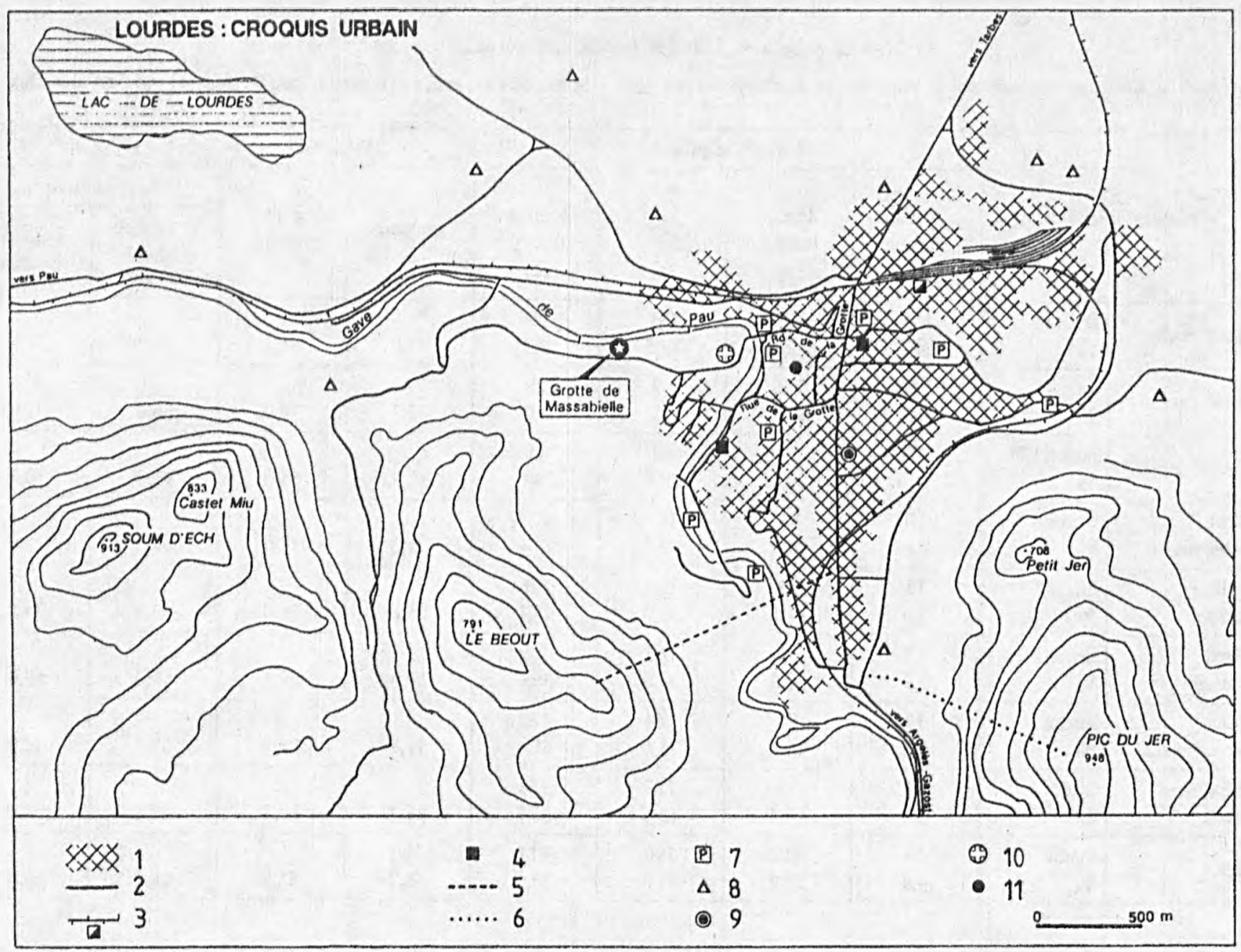

Rys. 1. Lourdes: szkic zarys miasta

1 - tkanka miejska; 2 - główne szlaki drogowe; 3 - linie kolejowe i dworzec SNCF; 4 - dworzec autobusowy; 5 - kolejka linowa; 6 - kolejka szynowo-linowa; 7 - główne parkingi; 8 - campingi; 9 - pałac kongresowy; 10 - bazylika St. Pie X; 11 - zamek (muzeum pirenejskie)

Dessin 1. Lourdes: Croquis urbain

1 - tissu urbain; 2 - voies routières principales; 3 -voies Ferrées et gare S.N.C.F.; 4 - gare routière; 5 - téléphérique; 6 - funiculaire; 7 - principaux parkings; 8 - terrains de camping; 9 - palais des Congrés; 10 - basilique St. Pie X; 11 - Château (Musée pyrénéen) 
całkowitego niezadowolenia jest bardzo niski - przeważnie poniżej 5. Należy w tym miejscu podkreślić, że wyniki te pochodzą z badań przeprowadzonych glównie wśród ludzi starszych, bardzo zadowolonych z pobytu w Lourdes. W wypowiedziach tych ludzi widoczne jest, ze specyfika motywacji turystycznej - entuzjastycznie przeżywana pielgrzymka - rekompensuje niepewność i ewentualne niedogodności związane $\mathrm{z}$ pobytem. $\mathrm{Z}$ drugiej strony wydaje się, iż turyści ci - jako słabo sytuowani - szczególnie czuli są na ceny usług. Odpowiednia relacja pomiędzy ceną i jakością dominuje nad wszelkimi innymi spostrzeżeniami respondentów. Niewątpliwie jednak wyniki te odzwierciedlają dobrą jakość instytucji świadczących usługi w Lourdes.

Odmiennie oceniana jest i ostro krytykowana organizacja ruchu turystycznego w mieście. Wyliczone wskaźniki sq tu wyraźnie niższe od średniej i oscylują okolo 25 . Ankietowane osoby jako zjawiska negatywne wymieniają brak płynności ruchu na ulicach miasta, trudności z parkowaniem pojazdów, oraz złe oznakowanie. Oceny te wyraźnie wskazują, iż przestrzeń miejska Lourdes znajduje się $w$ stanie pelnego nasycenia.

To pirenejskie miasto, liczące 17 tys. stałych mieszkańców, z coraz większym trudem wchlania coroczny napływ około $5 \mathrm{mln}$ pielgrzymów, którzy przybywają tam głównie w okresie od kwietnia do października. Napływ ten przejawia się w przestrzeni poprzez silne obciążenie dróg kolejowych oraz wypełnienie infrastruktury drogowej, szczególnie parkingów przez autokary i samochody, a zwłaszcza wszechobecność hoteli. Pod tym względem Lourdes rywalizuje we Francji z Nicę o drugie miejsce po Paryżu.

Tkanka tego miasta wydaje się być obecnie mało przystosowana do podejmowanych funkcji, a w rzeczywistości organizacja przestrzeni Lourdes jest efektem dzialających tu przeciwstawnych strategii. Jedną z nich reprezentują zakonnicy pragnący wyizolowania sanktuariów z przestrzeni miejskiej. Drugą - władze miejskie, które więcej uwagi przywiązują do spraw doczesnych. Biegun turystyczny i duchowy króluje dziś na lewym brzegu rzeki Gave w wyraźnym odosobnieniu. Miasto dolne rozciąga się półkoliście na lewym brzegu rzeki (rys. 1). Tkanka miejska poprzecinana jest bardzo gęstą siecią wąskich i krętych uliczek, wzdhuż których skupia się handel dewocjonaliami oraz hotele i restauracje. Stare miasto usytuowane poniżej zamku jest mało widoczne w zetknięciu z miastem górnym - bardzo świeckim i wręcz banalnym, pospolitym, przyjmującym układ liniowy. Działalność turystyczna koncentruje się obecnie $w$ kilku dzielnicach zajmujących najbardziej zróżnicowaną fizjonomicznie część miasta. Niektóre zbocza w tej części wyposażone sa w schody, a nawet posiadają windy umożliwiające pokonywanie wysokości. Sanktuaria lączą z miastem górnym i dworcem kolejowym dwie osie, które w czasie nasilonego ruchu pielgrzymkowego wypelnione są tłumami ludzi, co praktycznie uniemożliwia wszelki ruch samochodowy na tych szlakach. 
Rozbieżność interesów, o których była już mowa, utrudnia wszelkie planowe zagospodarowanie. Zezwolenia na budowę hoteli przyznawane są projektom bez uwzględnịenia problemów związanych z parkowaniem samochodów. Oznakowanie w mieście jest nieczytelne, a turyści stają wobec bezładnie rozmieszczonych i mnożących się znaków informacyjnych, co utrudnia, a nawet paraliżuje możliwość poprawnego odczytania informacji. Szyldy sklepikarzy i tablice reklamowe stoją obok siebie w największym nieładzie, zasłaniając często miejskie tablice informacyjne. Informacja nie jest ciągla, a trasy nie sa prawidlowo oznakowane. Wszystko to, na dodatek, jest bardzo różnorodne. Nie stosuje się żadnych reguł zarówno w wyborze kolorów tablic informacyjnych (władze miejskie używają np. koloru pomarańczowego i białego bez wyraźnego uzasadnienia kiedy - jaki) jak również w rozmieszczeniu drogowskazów, które raz umieszcza się nisko nad ziemią, innym razem zawiesza zbyt wysoko.

\section{WARUNKI POBYTU RÓZNYCH GRUP TURYSTÓW}

Ciągły wzrost ruchu turystycznego w Lourdes oraz zmieniające się motywacje przyjazdów i działdlności turystów stawiają obecnie $\mathrm{z}$ dużą ostrością problem warunków pobytu w tym mieście. Wyodrębnione w badaniach terenowych różne kategorie turystów-pielgrzymów w sposób kontrastowy odczuwaja warunki pobytu, jakie stwarza im to miasto.

Pielgrzymi podróżujący $w$ grupach zorganizowanych przez organizacje kościelne (parafialne czy diecezjalne) wykorzystują własne hotele, a pielgrzymka jest dla nich okazją do integracji. Obshuguje ich siedem biur turystycznych, dyktujących swoje ceny rozproszonemu sektorowi hotelarskiemu, który dysponuje okolo 400 obiektami o dominującej strukturze rodzinnej oferowanych pokojów. Ta grupa pielgrzymów nie napotyka na żadne trudności, a oznakowanie miasta czy parkowanie autobusów jest dla nich problemem marginalnym, rozwiązywanym sprawnie i fachowo przez znających miasto kierowców i przewodników. Są oni narażeni jedynie na stratę czasu wynikającą z tłoku komunikacyjnego, stanowiącego ogólną trudność w poruszaniu się po mieście.

W znacznie trudniejszej sytuacji znajdują się pielgrzymi indywidualni. Udając się do Lourdes własnymi środkami lokomocji są oni bardziej narażeni na wszystkie wymienione wcześniej przeszkody, które utrudniają im pielgrzymkę.

Należy również wyróżnić trzecią kategorię turystów, która korzysta z usług zawodowych organizatorów podróży, nie związanych z organizacjami kościelnymi. Zakres świadczonych ushug dla tej kategorii waha się od zagwarantowa- 
nia tylko transportu i ewentualnie hotelu, do pelnej gamy świadczeń potrzebnych pielgrzymowi. W zależności od zakresu zamówionych usług ksztaltuje się w tej grupie stopień zadowolenia $\mathrm{z}$ warunków pobytu w Lourdes. Oscyluje on jednak zawsze pomiędzy opiniami turystów indywidualnych i turystów zorganizowanych przez Kościól.

Najbardziej niezadowoloną grupę stanowili turyści indywidualni, którzy przybyli do Lourdes w znacznej liczbie (aż $46 \%$ spośród grupy osób badanych) w 48 godzin po zamknięciu Pielgrzymki Różańcowej w październiku 1990 r. Rozmowy prowadzone $\mathrm{z}$ tą grupą turystów w czasie sporządzania ankiety wskazują na tendencję powiększania się liczby turystów indywidualnych, co związane jest $\mathrm{z}$ powszechnie występującymi zmianami społecznymi wśród społeczeństw zachodnich, a zwlaszcza z rosnąca ruchliwością „mlodych emerytów".

Pielgrzymów indywidualnych charakteryzują postawy wyraźnie odmienne od zachowań pielgrzymów zorganizowanych. Są oni bardziej samodzielni, częściej przemieszczają się własnymi samochodami ( $50 \%$ badanych przyjechato własnym pojazdem), podczas gdy pielgrzymi zorganizowani przybywaja autokarem (53\%) i koleją (32\%). Pielgrzymi indywidualni są bezpośrednio narażeni na wszelkie niedogodności wynikające $\mathrm{z}$ samodzielnego poruszania się po źle przystosowanym dla turystów i nieznanym sobie mieście. Poprzez czynione obserwacje można było również stwierdzić, iż znajomość miasta przez jego mieszkańców jest dalece niekompletna i że niektórzy ze świadczących usługi (w szczególności sklepikarze nie wyspecjalizowani w sprzedaży dewocjonaliów) nie są zdolni do prawidłowego informowania turystów, co również jest pewnym utrudnieniem dla pielgrzymów indywidualnych. W Lourdes turystyka pozostaje sprawą tych, którzy z niej bezpośrednio żyją, a nie wszystkich mieszkańców.

Z większą ruchliwością tej grupy turystów lączy się również bardziej zdystansowany stosunek do religii. Ankiety wskazują, iż pobyt osób przybyłych tu indywidualnie przeżywany jest w sposób mniej jednoznaczny. Czysto religijną definicję Lourdes podało $72 \%$ pielgrzymów indywidualnych i $90 \%$ pielgrzymów zorganizowanych. Muzea świeckie, mieszczące się na terenie miasta, (Muzeum Pirenejskie, Muzeum Etnograficzne) bardziej przyciagają turystów indywidualnych, którzy dla odmiany rzadziej zwiedzają obiekty o wyraźnie religijnej tematyce. $\mathrm{Ci}$ sami pielgrzymi nabywają więcej pamiątek o charakterze regionalnym i lokalnym niż zorganizowani, których bardziej interesują pamiątki religijne. Różnice pomiędzy turystami inḋywidualnymi i zorganizowanymi występują również w zakresie wypełniania praktyk religijnych. We mszy świętej uczestniczy zaẃsze 19\% badanej grupy turystów indwidualnych, a $14 \%$ nie bierze w niej udziału nigdy. Dla turystów zorganizowanych liczby te wynoszą odpowiednio $30 \%$ i $4 \%$. Podczas pielgrzymki do Lourdes $73 \%$ turystów zorganizowanych uczestniczy w nabożeń- 
stwie drogi krzyżowej; wśród przybyłych tu indywidualnie udzial ten wynosi $47 \%$. W obu tych grupach przybycie do Lourdes ma jednak motywacje wyraźnie religijne. Wyrażają się one poprzez polaryzację w czasie i przestrzeni odwiedzania trzech miejsc: Groty, Bazyliki i figury ukoronowanej Matki Boskiej. Odwiedzanie innych miejsc wydaje się mieć charakter raczej marginesowy.

Zasygnalizowane tu zróżnicowanie zachowań pomiędzy pielgrzymami zorganizowanymi $\mathrm{i}$ indywidualnymi prowokuje do postawienia pytań dotyczących wspólistnienia tych grup turystów. Przeprowadzona analiza zachowań obu grup, jak również czynione w czasie badań obserwacje, wskazują na niewątpliwą konieczność poprawy wyposażenia terenów ,świeckich", nie związanych z kultem maryjnym. Wydaje się, iż najdogodniejsze bądą tu tereny położone wokól jeziora, których odpowiednie zagospodarowanie może wpłynąć na wydłużenie czasu średniego pobytu w Lourdes turystów indywidualnych.

Szybki rozwój turystyki pielgrzymkowej, a ogólnie turystyki miejskiej, przyciąga coraz większe rzesze turystów indywidualnych, bardziej ruchliwych i niezależnych, którzy w największym stopniu narażeni są na trudności wynikające ze zlego przygotowania miast, zwłaszcza w zakresie parkowania samochodów i oznakowania, a co za tym idzie, generalnie poruszania się. Także i Lourdes musi przygotować się na sprostanie tym nowym zachowaniom przybyszów. Rodzi się zatem pytanie: jak polepszyć ofertę turystyczną tego miasta? Propozycje, które przedstawiamy dotyczą w dużym stopniu poprawy najgorzej ocenianych aspektów organizacji pobytu w tym mieście, czyli organizacji ruchu, parkowania pojazdów oraz oznakowania ulic. W efekcie dotyczą one niekwestionowanego problemu restrukturyzacji przestrzeni miejskiej Lourdes.

\section{RESTRUKTURYZACJA PRZESTRZENI LOURDES}

Istniejące antagonizmy pomiędzy miastem dolnym - turystycznym i, ,zwykłym" miastem górnym w Lourdes stwarzają mało korzystny klimat dla inwestowania poważnych kapitalów miejskich w poprawę warunków przyjęcia turystów. Także wlaściciele hoteli, podzieleni strukturami rodzinnymi, nie mogą dojść do porozumienia w sprawie zaangażowania kapitałów w rozwój miejskiej infrastruktury turystycznej. Sytuacja zmusza jednak do podjęcia działań choćby usprawniających tylko poruszanie się po mieście. Do najpilniejszych prac, naszym zdaniem, należą sprawy oznakowania miasta i organizacji ruchu ulicznego. 


\subsection{OZNAKOWANIE MIASTA}

Przeprowadzone obserwacje wskazują na konieczność zastosowania w tym mieście ścisłych ograniczeń w zakresie rozmieszczenia i jakości oznakowania. Sposób oznakowania musi uwzględniać potrzeby turystów, tzn. wyprzedzać, dostarczać ciągłych informacji, uwzględniać różne rodzaje działalności (np. usługi pocztowe), a nie wskazywać wyłącznie miejsca przeznaczone do zwiedzania. Oznakowanie powinno również mieć charakter strukturalny, to znaczy że znaki rozmieszczone wzdluż tras powinny być uzupelnione przez punkty informacyjne dostarczające całościowej wiedzy o mieście. Trasy powinny być oznakowane w sposób ciągły, a znaki informacyjne muszą być bardziej widoczne, niezależnie od przyjętego kierunku poruszania się.

\subsection{ORGANIZACJA RUCHU ULICZNEGO}

Ruch uliczny w Lourdes jest chaotyczny, a jego koncentracja spowodowana współczynnikiem użytkowników różnych środków transportu, brakiem odpowiednich urządzeń i rozlicznymi sposobami użytkowania obszaru miejskiego (dotyczy to w szczególności nagromadzenia licznych straganów ulicznych).

W obecnej sytuacji niezbędne wydaje się podzielenie ruchu ulicznego na trzy sektory. Pierwszy sektor powinien być zarezerwowany dla pieszych. Dotyczy to najbliższego otoczenia sanktuarium po obu stronach rzeki Gave. Obszar ten powinien być otoczony parkingami, od których rozpoczynałoby się oznakowanie tras.

Drugi sektor bylby dozwolony dla ruchu samochodowego i komunikacji miejskiej. Dotyczy to w szczególności miasta górnego i peryferii miasta dolnego. Szczególną uwagę należy zwrócić na oznaczenie parkingów. Wreszcie autokary turystyczne powinny korzystać wyłącznie z głównyh dróg i arterii komunikacyjnych miasta, tworząc trzeci sektor ruchu miejskiego.

Niezbędne staje się również wlaściwe zagospodarowanie dróg wjazdowych do miasta. Lourdes nie uniknęło bowiem skutków współczesnego wzrostu i urbanizacji, co przejawia się m. in. w tym, iż drogi prowadzące do miasta obudowane zostały dwoma rzędami budynków supermarketów oraz różnych magazynów. Powoduje to, iz wjazd do miasta odbywa się w sposób niezauważalny, a przyjeżdżający nie ma świadomości ani przekraczania granicy, ani też miejsca swojego pobytu. Zjawisko to jest niekorzystne dla turystów i wymaga utworzenia konkretnych stref, które świadczyłyby o wjeździe do Lourdes („,bramy miasta”). W strefach tych można skoncentrować funkcję związaną z przyjęciem turystów, której celem byłoby dostarczenie wjeżdża- 
jącym niezbędnych wskazówek i informacji dotyczącyh tras miejskich czy możliwości rezerwacji pokojów hotelowych (obecnie turysta musi krążyć po mieście i poszukiwać miejsca w hotelu). Również plac przed dworcem kolejowym musi być traktowany jak jedna $z$ bram wjazdowych do miasta.

Przy realizacji tego założenia istniejące w mieście usługi turystyczne mogłyby podzilelić swoje funkcje. Funkcja kierownicza, organizacyjna i administracyjna turystyki może nadal być zlokalizowana w górnym mieście. Natomiast działalność związana z przyjmowaniem turystów musi przenieść się w stronę przyjeżdżających do dolnego miasta, w pobliże dużych parkingów drogowych i odpowiednio urządzonych wjazdów do miasta (,,bramy miejskie").

Za cenę bardziej rygorystycznego kierowania przepływem turystów i sektorowego zagospodarowania przestrzeni miejskiej Lourdes będzie mogło nadal pełnić swoją rolę światowego centrum pielgrzymkowego.

Prof. Christian Pihet

Wpłynęło:

Prof. Philippe Violier

15 sierpnia $1992 \mathrm{r}$.

Etudes Supérieures de Tourisme

et d'Hotellerie

de l'Université d'Angers

41, Place Louis Imbach

49100 Angers (Francja)

\section{RÉSUMÉ}

En octobre 1990, les étudiants de l'Université d'Angers, sur commande des autorités civiles et ecclésiastiques de la ville de Lourdes, ont fait l'examen des touristes-pèlerins y séjournant. Ils se sont servis d'une méthode d'enquête et d'observation. Les enquêtés dévaient évaluer l'organisation du mouvement touristique sur le terrain de la ville et des services rendus aux touristes.

Les résultats des recherches ont démontré que les touristes étrangers et ceux individuels les évaluaient différemment. Le premier groupe, au cas où c'était l'église qui avait entrepris l'organisation de son séjour, évaluait très favorablement la réception dans la ville et les conditions de demeure. Cela résulte du fait, que les organisateurs de l'excursion assurent l'arrivée sûre et confortable, le logement et le guide.

Tout à fait différentes (en leur masse) étaient les opinions exprimées par les touristes individuels, qui devaient eux-mêmes traverser la ville à la recherche d'un lieu de couchage, des endroits dignes d'être vus et observaient de nombreux manquements à l'organisation du mouvement intérieur (absence ou mauvaise exposition des informations, circulation routière mal organisée, problèmes de parking) et des services touristiques. Aussi faut-il signaler, que bien que, pour la plupart des arrivants, les objectifs religieux soient le motif principal de leur venue, les touristes individuels plus rarement participent aux offices (à l'oflice du chemin de la Croix ont pris 
part $73 \%$ des touristes organisés et $47 \%$ de ceux individuels) en visitant plus souvent les valeurs „laiques" de la ville (le Musée des Pyrénées, le Musée d'Ethnographie).

Les auteurs de l'examen ont conclu que l'espace existant de la ville de Lourdes doit être nécessairement reconstructuré. La restructuration devrait avant tout comprendre l'action de repérer la ville (entre autres par la création des zones d'information; servant de „portes d'entrée” dans la ville) et l'organisation du trafic routier. Ce dernier projet prévoit la division de la ville en trois secteurs destinés à la circulation pédestre, la circulation des voitures, et celle des autocars d'excursion.

Traduit par Lucjan Kowalski

\section{SUMMARY}

In October 1990 the students of the University of Angers were asked by the civil and church authorities of Lourdes to carry out a survey among the tourists-pilgrims who were arriving there. The survey and observation concerned the evaluation of the organization of the tourist traffic in the city and the services for the arriving tourists.

The results of the survey prove that there are noticeable differences in the evaluation between foreign tourists and individual tourists. The first group highly evaluated both the way they were welcome to the city and the conditions of their stay, especially when it had been orgnized by the church. It results from the fact that these tourists are taken full care of by the organizers, who see to smooth, safe arrival, satisfactory accomodation and provide a guide.

Opinions given by individual tourists were entirely different. They had to find their way about the city, places of interest and accomodation themselves. They pointed to faulty organization of the interior traffic (lacking or scarce information unorganized street traffic, problems with parking) and tourist services. It should also be pointed out that however for most people who arrive to Lourdes the main motive to go there is religious, yet the indvidual tourists less often take part in masses $(73 \%$ of the organized tourists and $47 \%$ of the individual tourists participated in the Way of the Cross). They are more interested in the secular places of interest in the city (the Pyrenean Museum, the Museum of Ethnography).

The conclusion drawn after the survey had been completed was that the present space of Lourdes should be restructured. Restructuring would, first of all, involve putting proper signs in the area of the city (e.g. information zones, which would be „entrance gates" to the city) and organization of the street traffic. The latter would mean dividing the city into three sectors - one for pedestrians, one for car traffic and one for trip coaches. 